\title{
ROOST AND FORAGE SITE FIDELITY OF WESTERN SMALL-FOOTED MYOTIS (MYOTIS CILIOLABRUM) IN AN OREGON DESERT CANYON
}

\author{
Thomas J. Rodhouse ${ }^{1}$ and Kenneth J. Hyde 2
}

\begin{abstract}
AвSTRACT.-We describe the roosting and foraging behavior patterns of western small-footed myotis (Myotis ciliolabrum) observed during a vertebrate inventory of the John Day Fossil Beds National Monument in north central Oregon. We used radiotelemetry to track 9 adult females, including 3 lactating and 6 postlactating bats, during July-September 2003. We found that these bats showed considerable fidelity to a common foraging area at the confluence of the John Day River and a tributary creek along which bats commuted and roosted. Individual bats did not roost together, but each showed high fidelity to local clusters of rock outcrops in small side canyons along the tributary. Roosts were not found in large, exposed cliff faces, despite the availability of such features. Rather, radio-tagged bats roosted in smaller outcrops that averaged $4.5 \mathrm{~m}$ in height. Bats commuted up to $12 \mathrm{~km}$ from roosts in the tributary canyon to the common foraging site at the river confluence and remained on the wing to forage for up to $4 \mathrm{~h}$ before returning to day roosts. No radio-tagged bats were observed using night roosts, even after pups were weaned. Our study provides a description of roosting, commuting, and foraging activity, as well as habitat use, of western small-footed myotis. This information provides a nuanced perspective on the ecology of canyon-dwelling bats in the region. Such perspective could be useful for conservation and habitat management.
\end{abstract}

Resumen.-Describimos el refugio y los patrones de comportamiento de desplazamiento del murciélago Myotis ciliolabrum observado durante un inventario de vertebrados del Monumento Nacional John Day Fossil Beds en el centronorte de Oregon. Utilizamos radiotelemetría para rastrear 9 hembras adultas, incluidas 3 lactantes y 6 post-lactantes, durante julio y septiembre del 2003. Encontramos que estos murciélagos mostraron fidelidad considerable a un área de alimentación común en la confluencia del Río John Day y a un arroyo tributario a lo largo del cual los murciélagos se desplazaban y dormían. Los murciélagos individuales no durmieron juntos, pero cada uno mostró una alta fidelidad a los grupos de rocas en pequeños cañones laterales a lo largo del afluente. Las perchas no se encontraron en grandes acantilados, a la vista, a pesar de la disponibilidad de tales características. Los murciélagos radio-etiquetados durmieron en afloramientos pequeños que estaban a $4.5 \mathrm{~m}$ de altura en promedio. Los murciélagos conmutaron hasta $12 \mathrm{~km}$ de perchas en el cañón tributario al sitio de desplazamiento común en la confluencia del río, y forrajearon hasta por 4 horas antes de regresar a los refugios de día. No observamos murciélagos radio-etiquetados utilizando refugios de noche, incluso después de que los cachorros fueron destetados. Nuestro estudio proporciona una descripción de los refugios, los desplazamientos, y la actividad de forrajeo y uso del hábitat del murciélago occidental que ofrece una perspectiva matizada sobre la ecología de los murciélagos que viven en cañones en una región que podría ser útil para la conservación y el manejo de su hábitat.

Understanding how animals utilize the landscapes where they live is fundamental to addressing questions pertaining to habitat selection and effectively conserving species and managing habitat. This is particularly true for volant animals such as bats because the distances they travel often exceed the boundaries of conservation areas. Thus, the success of conservation activities may be strongly affected by factors far outside the zone of influence of those activities. Knowing whether animals of conservation interest regularly return to important resources (i.e., exhibit site fidelity) can help in identifying key landscape features that can be targeted for protection. We used radiotelemetry techniques to observe the patterns of roosting, commuting, and foraging activities of female western small-footed myotis (Myotis ciliolabrum) in and around the John Day Fossil Beds National Monument in central Oregon, USA. The study was restricted to the 2003 summer pup-rearing season in a single desert canyon complex where the Clarno Unit of the national monument is located. Our objective was to determine how M. ciliolabrum utilized habitat resources in the vicinity of monument. We wanted to know whether there were geologic features (e.g., the monument's large fossil-bearing cliffs) or other features in the canyon landscape that were

1National Park Service, Upper Columbia Basin Network Inventory and Monitoring Program, 63095 Deschutes Market Road, Bend, OR 97701. E-mail: tom_rodhouse@nps.gov

${ }^{2}$ National Park Service, Lake Roosevelt National Recreation Area, 1008 Crest Drive, Coulee Dam, WA 99116 


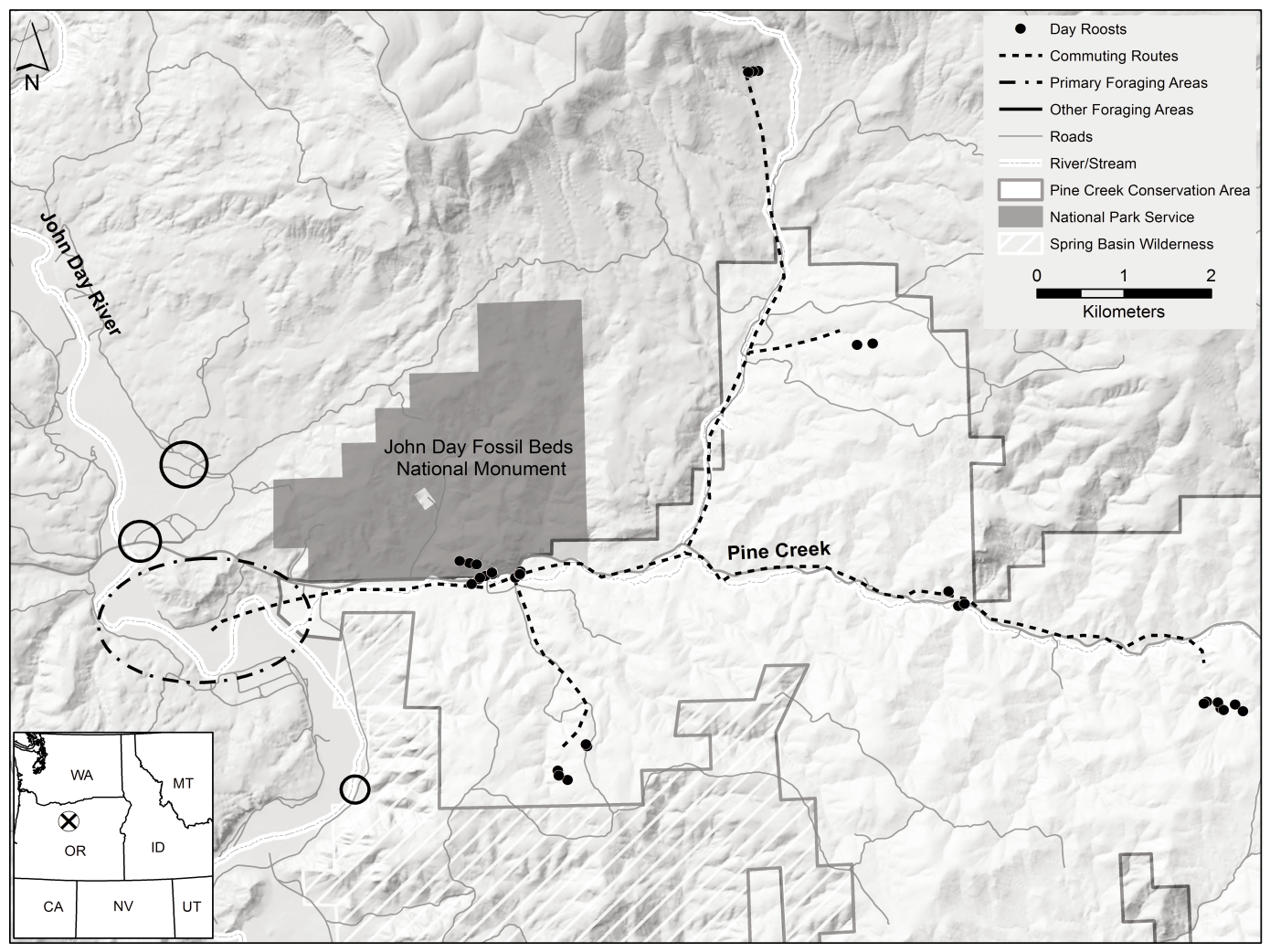

Fig. 1. The Clarno Basin study area, central Oregon, USA. Locations of day roosts, commuting routes, and foraging areas are shown for 9 female Myotis ciliolabrum radio-tracked in summer 2003. National Park Service and Pine Creek Conservation Area lands dedicated to habitat conservation within the basin are identified.

particularly important to bats and how use of those features by bats could inform habitat management and conservation. We targeted M. ciliolabrum because it is an abundant and characteristic species of the desert canyon study area, but one that has not been widely studied (Verts and Carraway 1998, Holloway and Barclay 2001). Information on roosting, commuting, and foraging habitat, including the distances traveled between roosting and foraging areas and the fidelity to those areas, is lacking for this species (Verts and Carraway 1998, Holloway and Barclay 2001).

Our study was conducted in the Clarno Basin of central Oregon (Fig. 1). The basin was formed from a large geologic syncline, resulting in a heavily eroded landscape bisected by the lower $15 \mathrm{~km}$ of Pine Creek to its confluence with the John Day River. Numerous side canyons occur along the length of Pine Creek, creating a network of potential travel corridors and roosting opportunities for rock-roosting bat species like M. ciliolabrum (Fig. 1). We conducted our research as part of an ongoing vertebrate species inventory for the John Day Fossil Beds National Monument, and we collected information on other species of bats (e.g., Rodhouse et al. 2005). A total of 14 species of bats regularly occurred in the study area (Rodhouse et al. 2005), which is exceptionally high species richness for Oregon (Verts and Carraway 1998). Other rock-roosting species characteristic of western deserts, including Euderma maculatum (spotted bat), Antrozous pallidus (pallid bat), and Parastrellus hesperus (canyon bat), were also common in the basin during our study (Lewis 1993, 1994, Rodhouse et al. 2005, 2011).

Elevations in the basin range from 395 to $1215 \mathrm{~m}$. At the time of study, the Clarno Basin received $<35 \mathrm{~cm}$ of precipitation annually and supported Juniperus occidentalis (western juniper) woodlands and shrubsteppe vegetation dominated by Artemisia tridentata (big 
sagebrush) and native perennial bunchgrasses. Actively irrigated cropfields were present along the John Day River in the vicinity of the Pine Creek confluence (Fig. 1). Along the floodplain benches of Pine Creek, abandoned fields that had been irrigated and planted with alfalfa and other livestock forage crops in previous decades supported dense seminatural vegetation dominated by nonnative Bromus tectorum (cheatgrass) and a number of weedy introduced forbs. Riparian vegetation, where it occurred, was dominated by Salix exigua (coyote willow) and Eleocharis spp. (spike-rush).

The study area was well suited for observing instrumented bats. Although the uplands in the basin were not accessible by roads, an infrequently traveled secondary road paralleled Pine Creek, and access roads were also conveniently located around the confluence and up some of the side canyons as well (Fig. 1). This road system facilitated our ability to locate and follow individual bats. Additionally, the 790-ha Clarno Unit of the national monument is adjacent to the 13,500 ha Pine Creek Conservation Area (owned by the Confederated Tribes of Warm Springs), and therefore much of the land in the basin is dedicated to conservation (Fig. 1).

Bats were captured with mist nets placed across beaver ponds along Pine Creek and across a dirt road along the edge of an agricultural field at the confluence. A dichotomous key from Verts and Carraway (1998) guided our field identification. Myotis ciliolabrum was differentiated from Myotis californicus (California myotis) primarily by considering the length of the tail that was exserted from the uropatagium (Constantine 1998) and pelage and facial skin color. We also evaluated the forehead slope and the length of the third metacarpal, which is shorter in M. ciliolabrum. Nine adult female M. ciliolabrum were fitted with 0.35 -g transmitters (model LB-2N, Holohil Systems Inc., Carp, ON, Canada) between 19 July and 25 September 2003. Transmitters represented $\leq 8 \%$ of the body weight of radio-tagged bats. We considered information contained in Aldridge and Brigham (1988), Brigham et al. (1997), Waldien et al. (2000), and Kurta and Murray (2002) to determine $8 \%$ as an acceptable upper limit. This decision was also consistent with updated guidance recently provided by Sikes et al. (2011). All M. ciliolabrum weighing $<4.5 \mathrm{~g}$ were excluded from the study. Bats weighing close to the 4.5-g limit were held for $20 \mathrm{~min}$ and reweighed before processing to allow for fecal material to be eliminated. No pregnant bats were radio-tagged, and a number of bats were released without being tagged because of weight concerns. Transmitters were attached to a small trimmed portion of the intrascapular region of bats by using Skin-Bond (Smith and Nephew United, Largo, FL). All bats were released within one hour of capture. Our capture and handling procedures were approved by the University of Idaho Institutional Animal Care and Use Committee (protocol \#2003-51).

Telemetry receivers (model TRX 1000-S, Wildlife Materials, Inc., Carbondale, IL), unidirectional vehicle roof antennas, and 5-element handheld directional yagi antennas were used to track bats to roosts and foraging areas. Signals were also monitored during exit counts to confirm bat departure times. Exit counts were performed by quietly sitting near crevices identified as roosts and monitoring radio signal strength and watching for bat activity. Emergence occurred before the end of civil twilight and spotlight illumination was not required to see bats. Measured roost characteristics included height, estimated from the base of the rock feature with the aid of an inclinometer and 100-m reel tapes; aspect, determined with a compass; the distance among roosts within clusters used by each bat; and the distance of the commuting route taken by each bat between roost and foraging site, measured in a geographic information system (GIS; Fig. 1). The coordinates of roost and capture site locations were recorded in Universal Transverse Mercator (UTM) projection with global positioning systems (GPS units). Commuting distances were then measured in a GIS as the total linear distance between roosts and the center of roost clusters to capture sites and to the center of approximated foraging activity ovals. We used a 2-tailed $t$ test to estimate the statistical significance of differences in commuting distances between lactating and postlactating bats and their roost clusters $(n=9)$.

Foraging M. ciliolabrum were tracked by directly homing in on bats and by monitoring the movement of the signal and the quality of signal attenuation (Amelon et al. 2009). We did not have adequate field personnel to effectively triangulate the position of foraging bats. However, bats concentrated their commuting routes along the Pine Creek corridor, which was traversed throughout its entire length by 
a secondary road, and they also concentrated their activity (presumably foraging) in agricultural fields at the confluence, which were easily circumnavigated by road and monitored from several high overlooks. We were often able to make visual contact with bats by using a spotlight to illuminate transmitter antennae. Two observers, each using separate vehicles, were often able to maintain contact with bats by "leapfrogging" each other along the road system that paralleled the creek. Radios remained attached to bats 4-12 days, and no transmitters or tagged bats were lost during the study. When time permitted, GPS units were used to collect waypoint locations where observations were made and where tagged bats were visually confirmed. We also returned to the area during the day to collect approximate locations. We used topographic maps to approximate locations and drew ovals to approximate the total area in which observations of use occurred.

A total of 9 bats were radio-tagged during the study, including 3 lactating bats and 6 postlactating bats. Roosts were located primarily in small side canyons adjacent to Pine Creek. However, early in the study while bats were still nursing pups, 2 lactating bats roosted in a large prominent cliff complex within the monument known as the "Palisades," which overlook Pine Creek (Fig. 2a). All roosts were located in narrow vertical or horizontal crevices in cliffs and rocky outcrops (Fig. 2). One roost was located under a boulder on a steep, rocky slope. Bats switched roosts frequently, yielding 43 discrete roost locations (Fig. 1). Eight roosts were each reused once ( 2 days total). One roost was reused 3 times (4 days total). Reuse was always on consecutive days. All other roosts received only one use during the study ( 1 day total). However, considerable fidelity to roosting areas was observed, and individual bats moved among a cluster of roosts within the same general cliff or outcrop complex during the period of observation. Average distance among roosts used by individual bats was $175 \mathrm{~m}$, and distances ranged from 30 to $347 \mathrm{~m}$. The farthest distance between roosts used by the same individual bat was $708 \mathrm{~m}$.

Twenty-eight roosts were located on small (e.g., $<10 \mathrm{~m}$ ), highly fractured rock outcrops tucked into side canyons (Fig. 2b). Fifteen roosts used by 2 bats were located on the large Palisades feature, although even these roosts were never on large, exposed faces of the cliff but were instead located in small alcoves near the top of the cliff away from the exposed cliff face (Fig. 2a). Roost heights averaged $4.5 \mathrm{~m}$ and ranged from 0 to $25 \mathrm{~m}$. However, lactating bats used roosts that were higher, on average $(n=$ $22, \bar{x}=7 \mathrm{~m}$ ), than those used by postlactating bats $(n=21, \bar{x}=2.3 \mathrm{~m})$. The mean aspect of roosts was $216^{\circ}$ and ranged from $10^{\circ}$ to $340^{\circ}$. Average commuting distance between capture sites and roosts was $4.4 \mathrm{~km}$ and ranged from 0.3 to $10.5 \mathrm{~km}$. However, all 9 bats routinely traveled from roosts to agricultural fields along the confluence; the fields were approximately 3 $\mathrm{km}$ farther downstream than the primary capture site on Pine Creek (Fig. 1). Lactating bats roosted in small clusters, and all postlactating bats were found roosting alone. Colony size, represented by exit counts, averaged 2 bats and ranged from 1 to 15 bats; the median colony size was one bat. On several occasions, we were able to peer into roost crevices during the day and confirm the presence of 2 bats, presumed to be the mother-pup pair.

Foraging observations were made on 38 nights during the study. Each of the 9 bats was tracked periodically as logistics permitted for 2 to 8 nights. We found that bats were predictable in timing of emergence and in commuting routes taken. This predictability made it easy to track them. Emergence times were relatively early, averaging $25 \mathrm{~min}$ after civil sunset and ranging from 8 to $35 \mathrm{~min}$. Bats were observed departing from roosts and flying out the side canyons to Pine Creek and then steadily working down the creek to foraging areas along the river confluence (Fig. 1). Foraging M. ciliolabrum were observed traveling long distances between roosting areas and foraging grounds. Mean distance to foraging areas was $6 \mathrm{~km}$ and ranged from 3 to $12 \mathrm{~km}$. The cluster of roosts located in the Palisades cliff complex and used by 2 lactating bats early in the study period was only $3 \mathrm{~km}$ from foraging areas. However, there was no detectable significant difference between lactating and postlactating bats in the distances from foraging ground to roost clusters $(P=0.55)$. High fidelity to particular foraging areas was exhibited among all bats during the observation period. Six bats were found foraging exclusively in an approximately $2.5-\mathrm{km}$ oval region centered on one large agricultural field and the adjacent riparian area along the John Day River and the mouth of Pine Creek (Fig. 1). The remaining 3 bats also used this area 


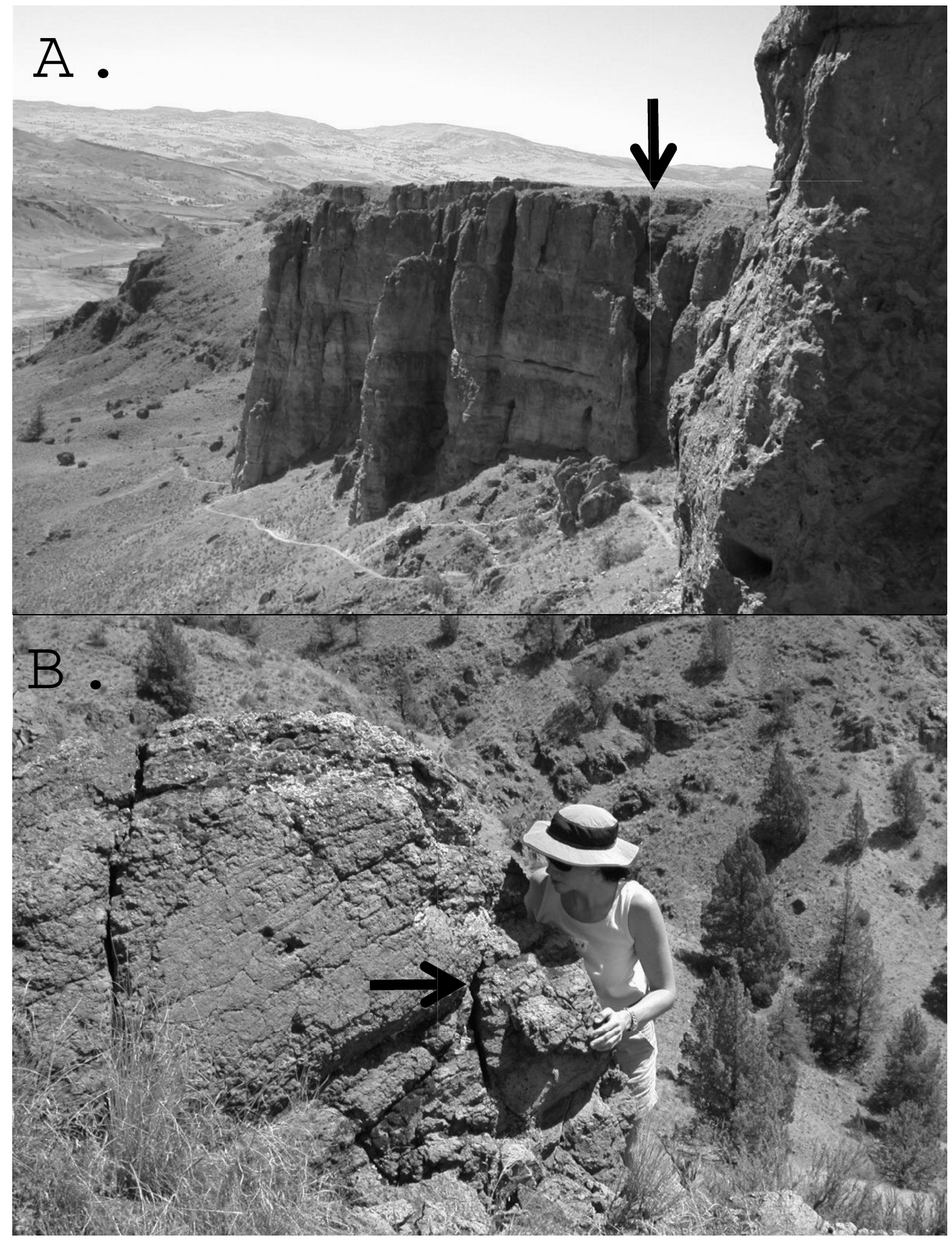

Fig. 2. Photographs of (A) the "Palisades" cliff complex in the John Day Fossil Beds National Monument, overlooking Pine Creek, and (B) a rock outcrop in a side canyon that was used as a roost by a female M. ciliolabrum in 2003. Roost locations are identified with black arrows. 
the majority of the time when observations were made. One bat was found foraging farther up river (south) along the bank of the river on 2 nights (Fig. 1). A second bat spent time in both the demarcated area and in agricultural fields north of Pine Creek along the river (Fig. 1), and one bat was followed up Pine Creek on one night, presumably on its way to forage, but was found foraging in the largest (primary) foraging oval later during that same night and on 2 other nights.

No tagged bats were observed using night roosts, but lactating bats tracked early in the study were observed returning to day roosts for short periods (i.e., $20 \mathrm{~min}$ ), presumably to nurse and move pups to new roosts. In August and September, during later stages of lactation and after weaning, bats were observed foraging continuously for $4 \mathrm{~h}$ or more before returning to day roosts for the remainder of the night. Visual observations were made of tagged bats foraging with other mixed species groups of small bats appearing to be Myotis and possibly Parastrellus hesperus. Bats foraged back and forth in small circuits at heights of $2-5 \mathrm{~m}$ over fields and low slopes and among small rock outcrops adjacent to the same fields. Bats also occasionally foraged low over the river in a manner similar to that typically associated with M. yumanensis (Yuma myotis; Verts and Carraway 1998).

The constellation of mapped observations of roosting, foraging, and commuting activity by 9 female $M$. ciliolabrum (Fig. 1) provides a unique glimpse into the summer habitat use patterns of this desert-dwelling species. Ball (2002) suggested that such a constellation could be considered an ecological neighborhood useful for addressing bat conservation and habitat management at the landscape scale appropriate for bats. Whereas most bat resource use studies and subsequent habitat management strategies have focused on roosts, Ball (2002) advocated for a more comprehensive approach that might include other areas of importance, such as the foraging and commuting routes identified in our study. This approach could be particularly effective for species that exhibit fidelity to resource areas over time. We observed a striking fidelity to roost clusters, commuting routes, and foraging grounds, although the behavior was not surprising given the reports of similar fidelity in other species of bats. Studies have shown that many species of bats will repeatedly use roosts and roosting areas within and among years (Lewis 1995, Barclay and Brigham 2001, Vielleux and Vielleux 2004). Some studies have also demonstrated fidelity to commuting and foraging areas (Racey and Swift 1985, Brigham 1991, Hillen et al. 2009, 2010).

The descriptions of roost characteristics and foraging habits obtained from our study are very similar to the largely anecdotal accounts provided in earlier studies (Verts and Carraway 1998, Holloway and Barclay 2001). For instance, Holloway and Barclay (2001) summarized that $M$. ciliolabrum commonly roosts in small colonies of one or a few bats in rock crevices and is known for early nightly emergence times. Holloway and Barclay (2001) also described a foraging strategy similar to the one we described, noting that M. ciliolabrum typically patrols circular beats over water and along riparian areas and rocky bluffs at low altitudes of 3-5 m. Verts and Carraway (1998) noted that very little was known about the species from Oregon. Our study provides perhaps the first descriptions of commuting distances and within-season fidelity to resource areas for this species. The concentration of foraging in actively irrigated cropfields underscores the potential ecological services that these bats may provide to farmers in the region, a topic receiving increased attention in the face of novel threats to bat welfare (Kunz et al. 2011).

Our observations suggest that lactating bats may have selected larger and possibly more secure or more thermally favorable roost structures than those selected later in the summer. It is striking that none of the instrumented bats moved out on to the main canyon of the John Day River, despite the numerous cliff-roosting opportunities available in very close proximity to foraging grounds. There may be an adaptive advantage that explains this behavior. For example, the added costs of long-distance commuting may be offset by more favorable thermal conditions in upland canyons. Regardless of the cause of this pattern, our results underscore the importance of taking a landscape- or neighborhood-based perspective to bat conservation. For example, the large Palisades cliff complex located on protected land within the John Day Fossil Beds National Monument may shift in importance for bats among seasons. This kind of spatial variability in resource selection within and among seasons underscores that a 
constellation or neighborhood of different key resource features spread over large landscapes is ultimately required to secure protected habitat for bats (Pierson 1998), a strategy emphasized by Ball (2002) and others (e.g., Hillen et al. 2010).

Lewis $(1993,1994)$ studied pallid bats in the Clarno Basin and found that maternity roosts were concentrated in and around the confluence and up into the lower portion of Pine Creek as far as the Palisades, rather than along the main river canyon. Rodhouse et al. (2011) found a higher foraging and commuting activity of $P$. hesperus in the downstream portion of another tributary of the John Day River, and that activily tapered off with increasing distance from the confluence. These patterns suggest that at a broader basin-wide scale, confluences and the lower portions of associated tributary canyons might serve as nodes that form a type of meta-neighborhood for regional summer populations of several species of bats. Oregon and Washington have numerous large high-order river basins in the arid lands east of the Cascade Mountain Range that provide complex canyon networks similar to those found in the John Day Basin. These canyon systems are likely hotspots of high bat species richness, particularly for the desert-canyon facultative species M. ciliolabrum, E. maculatum, P. hesperus, and A. pallidus (Verts and Carraway 1998, Rodhouse et al. 2005, 2011).

Patterns of animal habitat use are scale dependent, and our perception of what resources are important to animals often changes depending on the spatiotemporal grain and extent of study (Wiens 1989). For example, bats are often highly variable in their space use patterns over consecutive nights within a season, but highly predictable among seasons (Lewis 1995, Hayes 1997, Vielleux and Vielleux 2004). In a similar manner, bat occurrence patterns are much more predictable when viewed at broad spatial scales and coarse grain (e.g., $10-\mathrm{km}^{2}$ cells) than at finer scales (Rodhouse et al. 2012). Therefore, site fidelity and bat species-habitat relationships must be discussed with an explicit awareness of both spatial and temporal scale. The results of our study must be considered strictly within the scope of a single summer pup-rearing season. However, fidelity over time in roosting and foraging areas has been noted in other species (Racey and Swift 1985, Barclay and Brigham 2001, Hillen et al. 2010). Repeating a radiotelemetry study with $M$. ciliolabrum in the same study area would provide a much-needed temporal perspective on bat habitat selection that would be useful to bat conservation in North American desert ecosystems.

Funding for this project came from B. Frost, Great Basin Cooperative Ecosystem Studies Unit NPS Research Coordinator at the time of study, through a cooperative agreement with the University of Idaho CA\#9088A00008. The NPS Upper Columbia Basin Network and the John Day Fossil Beds National Monument provided additional funding and material resources. M. McCaffrey assisted with fieldwork, M. Lonneker assisted with mapping, and P. Ormsbee provided valuable comments during the preparation of the manuscript.

\section{Literature Cited}

ALDRIDGE, H.D., AND R.M. BRIgham. 1988. Load carrying and maneuverability in an insectivorous bat: a test of the $5 \%$ "rule" of radio-telemetry. Journal of Mammalogy 69:379-382.

Amelon, S.K., D.C. Dalton, and J.J. Millspaugh. 2009. Radiotelemetry: techniques and analysis. Pages 57-77 in T.H. Kunz and S. Parsons, editors, Ecological and behavioral methods for the study of bats. Johns Hopkins University Press, Baltimore, MD.

BALL, L.C. 2002. A strategy for describing and monitoring bat habitat. Journal of Wildlife Management 66: $1148-1153$.

Barclay, R.M.R., and R.M. BRigham. 2001. Year-to-year reuse of tree-roosts by California myotis (Myotis californicus) in southern British Columbia. American Midland Naturalist 146:80-85.

BRIGHAM, M.R. 1991. Flexibility in foraging and roosting behavior of the big brown bat (Eptesicus fuscus). Canadian Journal of Zoology 69:117-121.

Brigham, M.R., M.J. Vonhof, R.M.R. Barclay, and J.C. GWILLIam. 1997. Roosting behavior and roostsite preference of forest-dwelling California bats (Myotis californicus). Journal of Mammalogy 78: 1231-1239.

Constantine, D.G. 1998. An overlooked external character to differentiate Myotis californicus and Myotis ciliolabrum (Vespertilionidae). Journal of Mammalogy 79: 624-630.

Hayes, J.P. 1997. Temporal variation in activity of bats and the design of echolocation-monitoring studies. Journal of Mammalogy 78:514-524.

Hillen, J., A. Kiefer, And M. Veith. 2009. Foraging site fidelity shapes social organization of a population of female western barbastelle bats. Biological Conservation 142:817-823.

2010. Interannual fidelity to roosting habitat and flight paths by female western barbastelle bats. Acta Chiropterologica 12:187-195.

Holloway, G.L., and R.M.R. BarClay. 2001. Myotis ciliolabrum. Mammalian Species 670:1-5.

Kunz, T.H., E. Braun de Torrez, D. Bauer, T. Lobova, AND T.H. Fleming. 2011. Ecosystem services provided 
by bats. Annals of the New York Academy of Sciences 1223:1-38.

Kurta, A., AND S.W. Murray. 2002. Philopatry and migration of banded Indiana bats (Myotis sodalis) and effects of radio transmitters. Journal of Mammalogy $83: 585-589$

LEWIS, S.E. 1993. Effect of climatic variation on reproduction by pallid bats (Antrozous pallidus). Canadian Journal of Zoology 71:1429-1433.

1994. Night roosting ecology of pallid bats (Antrozous pallidus) in Oregon. American Midland Naturalist 132:227-233.

1995. Roost fidelity of bats: a review. Journal of Mammalogy 76:481-496.

Pierson, E.D. 1998. Tall trees, deep holes, and scarred landscapes: conservation biology of North American bats. Pages 309-325 in T.H. Kunz and P.A. Racey, editors, Bat biology and conservation. Smithsonian Institution Press, Washington, DC.

Racey, P.A., AND S.M. SwifT. 1985. Feeding ecology of Pipistrellus pipistrellus (Chiroptera: Vespertilionidae) during pregnancy and lactation: I. foraging behaviour. Journal of Animal Ecology 54:205-215.

Rodhouse, T.J., M.F. McCaffrey, and R.G. Wright. 2005. Distribution, foraging behavior, and capture results of the spotted bat in central Oregon. Western North American Naturalist 65:215-222.
Rodhouse, T.J., P.C. Ormsbee, K.M. Irvine, L.A. Vierling, J.M. SZEWCZAK, AND K.T. VIERLING. 2012. Assessing the status and trend of bat populations across broad geographic regions with dynamic distribution models. Ecological Applications 22:1098-1113.

Rodhouse, T.J., K.T. VierLing, and K.M. Irvine. 2011. A practical sampling design for acoustic surveys of bats. Journal of Wildlife Management 75:1094-1102.

Sikes, R.S., W.L. Gannon, and the Animal Care and Use Committee of the American Society of MamMALOGISTS. 2011. Guidelines of the American Society of Mammalogists for the use of wild mammals in research. Journal of Mammalogy 92:235-253.

Verts, B.J., and L.N. Carraway. 1998. Land mammals of Oregon. University of California Press, Berkeley, CA.

Vielleux, J.P., AND S.L. Veilleux. 2004. Intra-annual and interannual fidelity to summer roost areas by female eastern pipistrelles, Pipistrellus subflavus. American Midland Naturalist 152:196-200.

Waldien, D.L., J.P. Hayes, and E.B. ARnett. 2000. Dayroosts of female long-eared myotis in western Oregon. Journal of Wildlife Management 64:785-796.

Wiens, J.A. 1989. Spatial scaling in ecology. Functional Ecology 3:385-397.

Received 8 June 2013

Accepted 9 May 2014 